\title{
Pre-test Assessment of SOSA Bottle Intervention's Effectivity to Reduce Tuberculosis Spreading in Prisons
}

\author{
Syarifah Syarifah ${ }^{1}$, Sorimuda Sarumpaet ${ }^{2 *}$, Evawany Aritonang ${ }^{3}$ \\ ${ }^{1}$ Department of Health Education and Behavioral Sciences, Faculty of Public Health, Universitas Sumatera Utara, Medan, \\ Indonesia; ${ }^{2}$ Department of Epidemiology, Faculty of Public Health, Universitas Sumatera Utara, Medan, Indonesia; ${ }^{3}$ Department \\ of Community Nutrition, Faculty of Public Health, Universitas Sumatera Utara, Medan, Indonesia
}

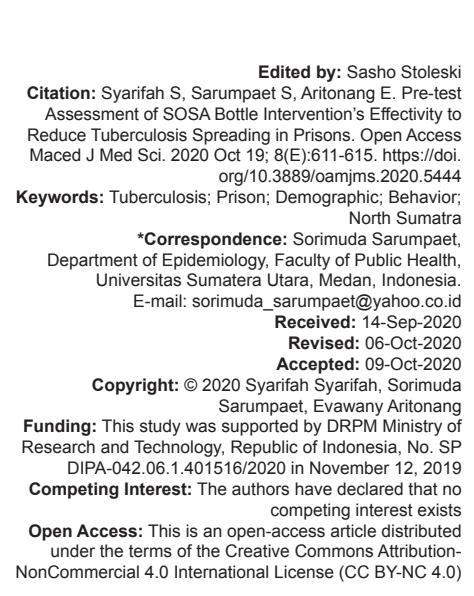

\section{Abstract}

BACKGROUND: Tuberculosis (TB) is still a health problem in the world, especially in Indonesia, TB still causes serious transmission, including in prison. The Sorimuda-Syarifah (SOSA) bottle, a bottle containing lysol, has been tested in the community and has given satisfactory results. Prison inmates and TB patients in prison urgently need better treatment in an effort to prevent the spread of TB and support its treatment.

AIM: This paper is the result of the pre-test, to assess the demographic profile and behavior of the respondents before giving SOSA bottles.

METHODS: The study was conducted using a questionnaire and was carried out on 27 prisoners in two separate locations in North Sumatra.

RESULTS: The demographic profiles of respondents were not much different, both in the intervention group and in the non-intervention group. After statistical tests were carried out, only knowledge was statistically significant. There are still a lot of knowledge, attitudes, and practice of respondents that support the spread of TB in prison.

CONCLUSION: The pre-test results indicate the need to implement the SOSA bottle in prisons

\section{Introduction}

The WHO states that pulmonary tuberculosis (TB) is the highest among the 10 largest infectious diseases in the world [1]. In the past 10 years, the countries with the highest incidence of TB were India, China, Indonesia, Nigeria, and Pakistan [2], [3]. In 2017, the incidence of TB in Indonesia ranks the second largest number of TB patients in the world, that is, 399 cases $/ 100,000$ population [4]. In the same year, North Sumatra Province, one of the provinces in West Indonesia, recorded the case detection rate of $52 \%$ with the case notification rate of $227 / 100,000$ populations.

The previous study revealed that if compared with the general population, the prevalence rate of TB in prisons and detention centers is higher [5], [6]. Prisoners with TB are the source of TB transmission not only to roommates and to prison officers but also to visitors. Unfortunately, prevention of TB in prisons is still not a major concern of health authorities, thus creating inequality of health status. Therefore, specific treatments are needed and adjustment with local intervention while possible is indispensable [7].
In fact, the Community Guided Prison (WBP) Jakarta, Bogor, Tanggerang and Bekasi area, the prevalence is reported 7.5 times higher than the community. From the report of the Ministry of Law and Human Rights of North Sumatra Province, it is known that from 2009 to 2011 TB cases in prisons increased by an average of $7.2 \%$ each year. From available data, TB ranks $4^{\text {th }}$ out of 10 diseases in prisoners and the second leading cause of death after HIV-AIDS, with 66 deaths. Of the 7972 TB suspects, 911 TB cases were found with 757 new smear-positive cases.

The capacity of prisons or detention centers that exceeds the normal capacity is a factor that increases the risk of TB transmission. Limited health human resources and inadequate infrastructure make TB easily circulate in prisons and put prisoners at great risk of being exposed to TB [8].

In Semarang, Central Java, the prevalence of TB infection cases in female prisoner's Class II A in Semarang City increased from 20\% (2014) to $26 \%$ (2015). The incidence of TB also increased by $18 \%$ in $2015-20 \%$ in 2016 [9]. This significant increase was partly due to the behavior of prisoners in prison, for example, the lack of personal precautions, including 
the habit of throwing sputum carelessly [10], [11]. For example, there was an effect of coughing behavior on the incidence of TB in Semarang prisons ( $p=0.022$; odds ratio $=3.927 ; 95 \%$ confidence interval: $1.288-8.440)$. It is also revealed that in 10 prison in narcotics Jakarta, of 3249 prisoners who were screened for TB, 180 were found to have suspected TB. Of the 18 people examined using the molecular rapid test (TCM) method, 3 were TB positive, 13 were TB negative, and 2 were invalid [12].

Previously, Sarumpaet and Syarifah (2018) [13] have successfully developed a bottle, mentioned as (Sorimuda-Syarifah [SOSA], also means "to wipe," in Batak language), to reduce TB transmission in community setting. The SOSA bottle, a watertight container and is resistant to lysol compounds when filled with 2-3 tablespoons (30-45 ml), can function as a disposal area for wipes and disposable masks from patients with TB (+). From the Health Centre experiment, the Mycobacterium tuberculosis germs in the SOSA bottle, have been proven, can be eradicated within $24 \mathrm{~h}$.

The results from the community showed that there was a significant reduction in the risk of transmission in the intervention group with the SOSA bottle compared to the non-intervention group. Thus, it is necessary to know how it can be applied in special locations such as in prisons. This present study aims to assess demographic and behavior profile of recruited prisoners who later will be trained to use SOSA bottles in prisons and detention centers.

\section{Methods}

As mentioned before, this whole study used a quasi-experimental research design pre-test and post-test design accompanied by a control group. The intervention group was given an SOSA bottle package (an SOSA bottle containing lysol, mask, and tissue) for 2 months and after 2 months was given TB socialization with video media for 2 times. Meanwhile, the nonintervention group was only given an SOSA bottle package without getting any TB socialization. This research is the result of the pre-test of the respondents before receiving the SOSA bottle.

This research was conducted in the Class I Medan Prison and the Class II B Lubuk Pakam prison as the location for the intervention group and the Class I State Prison in Medan as the location for the control group.

There were 27 participants of this study. The inclusion criteria are (1) TB patients who do not experience complications of other serious diseases and (2) willing to become respondents. Exclusion criteria were TB patients who were unable to be interviewed.

The research variables consisted of respondent's demographics and behavior.
Demographics of respondents are age ( $\leq 40$ years old and $>40$ years old), education (low=never attend formal school/did not complete elementary school/ finished junior high school and high=senior high school to academy/college), marital status (married and unmarried [including not married, widowed/widowed/divorced/ others], and previous occupation (not work and work). Meanwhile, behavior consists of knowledge, attitudes, and practice [14]. Knowledge is the respondent's knowledge about TB. Knowledge is measured using a scoring and weighting system measurement scale. Attitude is respondent's response to prevention of TB transmission. Measurement of attitudes using a Likert scale with answer categories is strongly agree (4), agree (3), disagree (2), and disagree (1). Practice is the action of TB patients to break the chain of transmission of TB which includes the habit of expelling phlegm, the habit of using a container, and the habit of using a mask.

\section{Data collection}

Data were obtained using questionnaire that has been tested for its validity and reliability. The questionnaire was distributed to respondents after ethical approval from the Health Ethics Committee of the Faculty of Nursing, University of North Sumatra with No. 217/VI/SP 2020 and consent from respondents. Trained health workers were deployed to do data collection and send to the research team through the network (online).

\section{Data analysis}

Univariate analysis was performed by presenting frequency distribution data and bivariate analysis using the Mann-Whitney U-test at $95 \%$ confidence level.

\section{Results}

Table 1 shows that for the two groups, the largest proportion of the age group was $\leq 40$ years, as much as $72.2 \%$ in the intervention group and $55.6 \%$ in the

Table 1: Respondent's demographic profile

\begin{tabular}{|c|c|c|c|c|c|}
\hline \multirow[t]{2}{*}{ Variable } & \multirow[t]{2}{*}{ Category } & \multicolumn{2}{|c|}{ Intervention group } & \multicolumn{2}{|c|}{ Non-intervention group } \\
\hline & & $f$ & $\%$ & $f$ & $\%$ \\
\hline \multirow[t]{2}{*}{ Age } & $\leq 40$ years old & 13 & 72.2 & 5 & 55.6 \\
\hline & $>40$ years old & 5 & 27.8 & 4 & 44.4 \\
\hline \multirow[t]{2}{*}{ Education } & Low & 9 & 50 & 4 & 44.4 \\
\hline & High & 9 & 50 & 5 & 55.6 \\
\hline \multirow[t]{2}{*}{ Marriage status } & Married & 13 & 72.2 & 6 & 66.7 \\
\hline & Not married & 5 & 27.8 & 3 & 33.3 \\
\hline \multirow[t]{4}{*}{ Previous working status } & No & 0 & 0 & 4 & 44.4 \\
\hline & Labor & 4 & 22.2 & 5 & 55.6 \\
\hline & Student & 1 & 5.6 & 0 & 0 \\
\hline & Private job & 13 & 72.2 & 0 & 0 \\
\hline \multirow[t]{2}{*}{ Smoking habit } & Yes & 10 & 55.6 & 9 & 100 \\
\hline & No & 8 & 44.4 & 0 & 0 \\
\hline \multirow[t]{2}{*}{ Previous history of TB } & Yes & 2 & 11.1 & 2 & 22.2 \\
\hline & No & 16 & 88.9 & 7 & 77.8 \\
\hline
\end{tabular}


non-intervention group, respectively. Meanwhile, when viewed from education, both low and high educated in the intervention group were equal to $50 \%$. Meanwhile, in the non-intervention group, the proportion with higher education was slightly higher (55.6\%). It can also be seen from the marital status that the majority of TB patients in the intervention group are already married $(72.2 \%)$ while in the non-intervention TB patients, only $66.7 \%$ are married. Meanwhile, the majority of TB patients in the intervention group worked as entrepreneurs (72.2\%), while the majority of TB patients without intervention worked as laborers (55.6\%). The smoking habit in patients with intervention TB was only $55.6 \%$, while all non-intervention TB patients smoked (100\%).

Based on Table 2, it can be seen that the mean value of knowledge of respondents in the intervention group is 23.11 and that of non-intervention respondents is 32.44 with a value of $p>0.05(p=0.067)$, which means that there is no significant difference between the respondent's knowledge and the respondent's category. A total of $44.4 \%$ of the intervention respondents had a knowledge score below the mean and $55.6 \%$ had a knowledge score above the mean. Meanwhile, $83.3 \%$ of the non-intervention respondents had knowledge scores below the mean and $16.7 \%$ had scores above the mean.

Table 2: Statistic's differences between the intervention and non-intervention groups

\begin{tabular}{llllllll}
\hline Behavior item & Group & $\mathrm{n}$ & Mean & $\mathrm{SD}$ & Median & Min-max & $\mathrm{p}$-value \\
\hline Knowledge & Intervention & 18 & 23.11 & 11.071 & $3-36$ & $3-36$ & $0.067^{*}$ \\
& Non-intervention & 9 & 32.44 & 9.645 & $17-47$ & $17-47$ & \\
Attitude & Intervention & 18 & 41.94 & 24.604 & 55 & $0-67$ & 0.088 \\
& Non-intervention & 9 & 55.22 & 17.254 & 62 & $10-64$ & \\
Practice & Intervention & 18 & 9.11 & 5.075 & 12 & $0-13$ & 0.558 \\
& Non-intervention & 9 & 11.89 & 1.054 & 12 & $10-13$ & \\
\hline n=Number. SD= Standard deviation: min=Minimum value; & max=Maximum value. & &
\end{tabular}

Based on Table 2, it is presented that the median value of the intervention respondent's attitude is 55 and the non-intervention respondent is 62 with $p>0.05(p=0.088)$, which means that there is no significant difference between the respondent's attitude and the respondent's status. A total of $44.4 \%$ of the intervention respondents had an attitude score below the median and $55.6 \%$ above the median. Meanwhile, the non-intervention respondents had $55.6 \%$ of respondents who had attitude scores below the median and $44.4 \%$ above the median.

Based on Table 2, the practice of the intervention and non-intervention respondents has an average value of 12 with a minimum score of 0 and a maximum of 13 for the intervention respondents, while for the non-intervention respondents, the minimum score is 10 and a maximum of 13 with $p>0.05$ ( $p=0.558$ ), which means that there is no significant difference between the respondent's practice and the respondent's status. As many as $44.4 \%$ of the intervention respondents had scores below the median and $55.6 \%$ above the median, while $33.3 \%$ of the nonintervention respondents had scores below the median and $66.7 \%$ above the median.

\section{Discussion}

This research attempts to address serious problems that have never been mainstreamed in TB control policies in Indonesia and perhaps also in countries with quite large TB cases. Considering the significant impact of TB [15], [16], prisoners' health condition cannot be neglected, regardless of their status.

This study shows that in the early stages before the intervention was implemented, the two study groups had shown similar demographic profiles. The education and marital status of the two groups were similar, while the older age was more dominant in the intervention group. However, the previous work was more dominated by workers in the non-intervention group, while those in the intervention group were more dominated by entrepreneurs. Except that in the intervention group, the percentage of smokers was only about half that of the non-intervention group. Likewise regarding previous TB exposure, the intervention group also reached half of the non-intervention group.

Statistically, only knowledge was different between the two groups. Meanwhile, the attitudes and practices of the two groups were not much different. However, when viewed from the mean score, the knowledge, attitudes, and practices of the intervention respondents were lower than those of the nonintervention respondents.

If we look more deeply at the questionnaire material provided, the main problem is the incomplete knowledge of the respondents. For example, in the intervention respondent group, the majority did not know the definition of TB (47.6\%). Both groups generally answered correctly when asked about the modes of transmission of TB. For example, when this question was asked, the answer "through coughing and sputum sprinkling" was answered correctly by $70 \%$ of respondents in the intervention group and $77.8 \%$ of respondents in the non-intervention group. However, not all of the answers were answered correctly by all respondents. Likewise regarding TB symptoms, causes of TB and TB transmission methods, most respondents only knew very little.

Knowledge certainly cannot be separated from attitude. The attitudes of the two groups were not different, indicating that the two groups did not show an attitude that was important in preventing TB transmission. Based on the response data of respondent's attitudes in the questionnaire, regarding the statement that TB can transmit through sputum sparks, the majority of intervention respondents answered strongly disagreed (33.3\%), while the the majority of non-intervention respondents answered strongly agree (77.8\%). Regarding coughing behavior, $50 \%$ of the intervention respondents answered strongly agree that if they cough and sneeze, they must cover their mouths and the majority of the non-intervention 
respondents answered agree (66.7\%). These two facts reveal that the attitudes of the two groups are still not very supportive of TB prevention.

Finally, the practice of the respondents. Based on the respondent's answer when giving question, "the most important prevention is avoiding prolonged contact with TB patients," $55.5 \%$ of the intervention respondents answered yes. Meanwhile, $77.8 \%$ of the non-intervention respondents answered yes. Another important question concerns the consumption of TB drugs. A total of $72.2 \%$ of respondents with intervention and $77.8 \%$ of respondent's non-intervention answered that "TB drugs must be taken every day." The facts above show that there are still quite a few respondents who do not practice avoiding TB transmission, thus putting them at risk of contracting TB in addition to not obidient in taking TB drugs. Such behavior clearly goes against the advice they should be fulfilling.

Since this study will introduce the SOSA bottle at a later stage, it requires information about the current habits of the respondents. Based on the respondent's respond, only $72.2 \%$ of the intervention respondents answered that they prepared a container to collect their sputum. When specified, $44 \%$ answered using tin containers, $11.1 \%$ plastic bag containers, and $16.7 \%$ bottles. When viewed according to the group, the intervention respondents used lysol (22.2\%), water $(22.2 \%)$, and carbolic acid $(5.6 \%)$ as the contents of the container. As many as, $38.9 \%$ of the intervention respondents disposed of the contents of the container into the trash can and $22.2 \%$ disposed of the toilet. For the non-intervention respondents, $66.7 \%$ answered that they prepared a container to collect their sputum, including $22.2 \%$ using tin containers and $22.2 \%$ using plastic bags. The contents used in the container were lysol $(44.4 \%)$ and carbolic acid $(22.2 \%)$. As many as, $22.2 \%$ answered that they dumped the contents of the container into the trash can, toilet, and even ditch. Hence, it is clear here that not all respondents use a container to collect sputum and it is clearly very dangerous. Disposing of sputum without adequate care will result in TB transmission in a prison environment.

The use of containers as a place to dispose of sputum is indeed one way to break TB's transmission. Especially if in the container, there are active ingredients such as lysol and carbolic acid which are active ingredients that kill bacteria that cause TB. In addition, apart from being a place to dispose of sputum, containers can also be used to dispose of used masks and tissues from TB patients because tissues and masks are one of the media that can spread TB bacteria to other people if they are put and thrown away anywhere.

Research by Sarumpaet and Syarifah at the Medan city health center showed that the SOSA bottle containing $5-20 \%$ lysol as a place to dispose of sputum can reduce the risk of TB transmission in TB patients compared to patients without SOSA bottles $(p<0.05)$ [13].
Prison is an important place for intervention by introducing new habit. It is clear that there is a relationship between the habits of throwing saliva with the incidence of TB disease [17]. In Kendari Class II A prison, the habit of throwing sputum carelessly increases the risk of developing TB [11]. In this study, observations were made regarding the habit of disposing of sputum by inmates. It was seen that detainees were accustomed to throwing sputum in random places, for example, beside the bed and in the surrounding environment [5]. Thus, efforts to conduct experiments as a follow-up to this pre-test will be very important to control TB transmission in specific environments such as prisons.

\section{Conclusion}

The pre-test shows that the respondents' knowledge, attitudes, and practice are still very low, so it requires experiment-based efforts. Prisons are very important locations because those who are detained have limitations in protecting themselves. This research will be very useful to improve the health quality of prisoners.

\section{Acknowledgment}

This research is funded by DRPM Ministry of Research and Technology, Republic of Indonesia, No. SP DIPA-042.06.1.401516/2020 in November 12, 2019. The authors express sincere gratitude to the government of Indonesia.

\section{References}

1. World Health Organization. Global Tuberculosis Report 2019 Geneva, Switzerland: World Health Organization; 2019.

2. World Health Organization. WHO Operational Handbook on Tuberculosis. Geneva, Switzerland: World Health Organization; 2020.

3. World Health Organization, SEARO. Tuberculosis Control in the South-East Asia Region, Annual Report 2016. Geneva, Switzerland: World Health Organization, SEARO; 2016.

4. Ministry of Health. Infodatin Tuberculosis. New Delhi: Ministry of Health; 2018.

5. Ilievska-Poposka B, Zakoska M, Pilovska-spasovska K Simonovska L, Mitreski V. Tuberculosis in the prisons in the republic of Macedonia, 2008-2017. Open Access Maced J Med Sci. 2018;6(7):1300-4. https://doi.org/10.3889/ oamjms.2018.281 
PMid:30087741

6. Dolla CK, Dhanraj B, Malaisamy M, Priyadarshini CP, Hissar SS, Natrajan $\mathrm{M}$, et al. Burden of pulmonary tuberculosis in modern prison: A cross sectional prevalence survey from south India. Indian J Tuberc. 2019;66(1):189-92. https://doi.org/10.1016/j. ijtb.2018.10.007

PMid:30878067

7. Dara M, Acosta CD, Melchers NV, Al-Darraji HA, Chorgoliani D, Reyes $\mathrm{H}$, et al. Tuberculosis control in prisons: Current situation and research gaps. Int J Infect Dis. 2015;32:111-7.

PMid:25809766

8. Ministry of Law and Human Right. Report of Ministry of Law and Human Right. Indonesia: Ministry of Law and Human Right; 2012.

9. Dewi AIC. Faktor Yang Berhubungan Dengan Insiden TB Paru Pada Penghuni Lapas Perempuan Klas II Semarang, Under Graduates Thesis. Indonesia: Universitas negeri Semarang; 2016.

10. Thuffi R. Occurrence Risk of Tuberculosis: Case Control Study at Correctional Inmates in Class II Narcotics Penitentiary Jakarta in 2013. Indonesia: Universitas Indonesia; 2013.

11. Hidayat $R$, Bahar $H$, Ismail $C$. Skrining dan studi epidemiologi penyakit tuberkulosis paru di lembaga pemasyarakatan kelas ii a Kendari tahun 2017. J IIm Mhs Kesehat Masy Unsyiah. 2017;2(6):183040.

12. Putri EA, Martini M, Saraswati LD, Adi MS. Faktor risiko tuberkulosis paru pada warga binaan pemasyarakatan di lembaga pemasyarakatan Kelas I Semarang. J Kesehat Masy. 2018;6(1):245-52. https://doi.org/10.24176/sk.v19i2.3228

13. Sarumpaet $S$, Syarifah $S$. Correlation between pulmonary tuberculosis (TB) patient's characteristics and role of supervisor of drugs swallowing (PMO) with the risk of transmission in Medan city 2017. Indian J Public Heal Res Dev. 2019;10(1):1209. https://doi.org/10.5958/0976-5506.2019.00220.1

14. Zaluchu F. Metodologi Penelitian Kesehatan. Karnataka: Cipta Pustaka Media; 2006

15. Collins D, Hafidz F, Suraratdecha C. The Economic Burden of Tuberculosis in Indonesia. ???: ???; 2013.

16. Christine $T$, Tarigan AP, Nainggolan N, Zaluchu F. Hubungan kadar transforming growth factor-B dengan gambaran fibrosis paru pada pasien pasca TB paru di Medan. J Respirol Indones. 2020;40(1):8353. https://doi.org/10.24114/jkss.v16i31.10174

17. Masdalena M, Hasan W, Hiswani H. Pengaruh hygiene dan sanitasi lingkungan terhadap penyakit tuberculosis paru pada warga binaan pemasyarakatan di Blok D Rumah Tahanan Negara Kelas 1 Medan. PRIMER (Prima Med J). 2018;1(1):12 24. https://doi.org/10.32503/jmk.v5i2.1000

Author Query???

AQ7: Kindly provide publisher details 